\title{
Gull Colony at Waterhen Marsh
}

\author{
By Judge L. T. McKim
}

$0^{N}$ JUNE 15, Mrs. McKim and I spent the day on Waterhen Marsh near Kinistino. We found the nesting sites of hundreds of Franklin Gulls. The birds nest among the rushes where the water is from a foot to eighteen inches deep. The nests are raised up well above the water and each contained from one to three eggs.

The birds flew low overhead in great numbers protesting our intrusion in no uncertain terms. It was one of the most beautiful sights we ever saw and would have made a grand movie, as the birds were so densely massed that fifty or more were within a hundred feet of us at one time.

Within a very short distance of each other on the bank of the canal that once drained the marsh, we found three ducks' nests. One had four large eggs and four a little bigger than warblers', smaller than usually laid by an any duck but unquestionably duck eggs. As one of my mallards laid an even smaller egg this spring, I believe they were all laid by a mallard. Another nest had ten Scoup eggs in it and three very large eggs; also a Teal's nest had seven of her eggs and one large one. It could be that the same duck laid in three nests.

We ate lunch on the bank of the canal near where a Canada Goose had successfully hatched a brood. In a bay of the lake we saw eight of these geese, perhaps last year's birds that had not mated. There is no question but these geese are making their summer home at Waterhen.

Gulls were all over the huge marsh and on the cultivated fields around it. I would estimate that not less than 500 gulls have taken up their summer home here. In a dozen places we found that ducks' eggs, Mallards I think, have been eaten, I presume by crows. An investigation some time ago showed that $39 \%$ of the nests on the canal bank are destroyed by crows.

\section{Oven Birds at Spirit Lake By William Anaka}

$\mathbf{O}^{\mathrm{N}}$ MAY 23 I found a partly completed Oven Bird's nest in the bush about thirty yards from my home. C. Stuart Houston in his "Birds of the Yorkton District", lists the bird as an uncommon migrant, nesting just north of the Yorkton area.

The nest was on the ground, made of grass, leaves and rootlets, completely roofed over, with a side entrance. The bird was rather shy, keeping at a good distance and flitting around so quickly that I had a difficult time trying to get a good look at it. I finally identified it by the sharply striped breast and yellowish-orange crown stripe. Its distinctive song: "teacher, teacher, teacher, teacher" - the notes rising in volume, could be heard every day for several weeks after the young had left the nest.
There was some interference from Cowbirds and there was only one Oven Bird's egg in the nest at the time of hatching.

\section{Buntings}

Helen and Herbert Partridge, Gull Lake

$\mathbf{T}$ here being plenty of moisture this year in our dry district, there is the greatest variety of water-birds seen for some years. Last year we observed man y Yellow-headed Blackbirds; this year have been rewarded with but one specimen. Our wide rolling country is a great haven for the Lark Bunting. We were much interested in this delightful visitor. On June 26 we were fortunate enough to see a Lazuli Bunting. This is one of the most beautiful birds we have ever observed. It appears to feed on caraganas and comes close to the house. The blue head of this beauty, glittering in the sunshine, is a sight to behold. 